Review

\title{
Review on the Safe Use of Ammonia Fuel Cells in the Maritime Industry
}

\author{
Michail Cheliotis ${ }^{1, *,+} \mathbb{D}$, Evangelos Boulougouris ${ }^{1} \mathbb{D}$, Nikoletta L Trivyza ${ }^{1,+}$, Gerasimos Theotokatos ${ }^{1}$ D, \\ George Livanos ${ }^{2}$, George Mantalos ${ }^{3}$, Athanasios Stubos 4 , Emmanuel Stamatakis 4,5 (D) \\ and Alexandros Venetsanos ${ }^{4}$
}

1 Maritime Safety Research Centre, University of Strathclyde, Richmond Street 16, Glasgow G1 1XQ, UK; evangelos.boulougouris@strath.ac.uk (E.B.); nikoletta.trivyza@strath.ac.uk (N.L.T.); gerasimos.theotokatos@strath.ac.uk (G.T.)

2 CAPITAL-EXECUTIVE Ship Management Corp, 3, Iasonos Street, 18537 Piraeus, Greece; gi1@capital-executive.gr

3 STARBULK, 40, Agiou Konstantinou, 15124 Athens, Greece; gmantalos@starbulk.com

4 NCSR “Demokritos”, Agia Paraskevi, Attikis, 15310 Athens, Greece; stubos@ipta.demokritos.gr (A.S.); manos@ipta.demokritos.gr or estamatakis@ipr.forth.gr (E.S.); venets@ipta.demokritos.gr (A.V.)

5 Institute of Petroleum Research-FORTH, 73100 Chania, Greece

* Correspondence: michail.cheliotis@strath.ac.uk

+ These authors contributed equally to the content of the paper.

check for updates

Citation: Cheliotis, M.; Boulougouris, E.; Trivyza, N.L; Theotokatos, G.; Livanos, G.;

Mantalos, G.; Stubos, A.; Stamatakis,

E.; Venetsanos, A. Review on the Safe Use of Ammonia Fuel Cells in the Maritime Industry. Energies 2021, 14, 3023. https://doi.org/10.3390/ en14113023

Academic Editor: Antonino S. Aricò

Received: 26 April 2021

Accepted: 18 May 2021

Published: 23 May 2021

Publisher's Note: MDPI stays neutral with regard to jurisdictional claims in published maps and institutional affiliations.

Copyright: (c) 2021 by the authors. Licensee MDPI, Basel, Switzerland. This article is an open access article distributed under the terms and conditions of the Creative Commons Attribution (CC BY) license (https:// creativecommons.org/licenses/by/ $4.0 /)$.

\begin{abstract}
In April 2018, the International Maritime Organisation adopted an ambitious plan to contribute to the global efforts to reduce the Greenhouse Gas emissions, as set by the Paris Agreement, by targeting a 50\% reduction in shipping's Green House Gas emissions by 2050, benchmarked to 2008 levels. To meet these challenging goals, the maritime industry must introduce environmentally friendly fuels with negligible, or low $\mathrm{SO}_{X}, \mathrm{NO}_{X}$ and $\mathrm{CO}_{2}$ emissions. Ammonia use in maritime applications is considered promising, due to its high energy density, low flammability, easy storage and low production cost. Moreover, ammonia can be used as fuel in a variety of propulsors such as fuel cells and can be produced from renewable sources. As a result, ammonia can be used as a versatile marine fuel, exploiting the existing infrastructure, and having zero $\mathrm{SO}_{\mathrm{X}}$ and $\mathrm{CO}_{2}$ emissions. However, there are several challenges to overcome for ammonia to become a compelling fuel towards the decarbonisation of shipping. Such factors include the selection of the appropriate ammonia-fuelled power generator, the selection of the appropriate system safety assessment tool, and mitigating measures to address the hazards of ammonia. This paper discusses the state-of-the-art of ammonia fuelled fuel cells for marine applications and presents their potential, and challenges.
\end{abstract}

Keywords: zero-carbon; shipping; ammonia; power production; fuel cells; safety

\section{Introduction}

It is without a doubt a new era for the maritime industry, full of challenges that are poised to disrupt the status quo of common practices. The current coronavirus pandemic, the looming dangers of climate change and the novelties of smart shipping are the main contributing factors that catapult the maritime industry in an era of uncertainty. The severity of the challenges ahead is speculated to be as severe as those brought upon by the transition from sails to steam power [1]. Excluding the worst-case scenario of the impact of the pandemic to sea trade, the effects of the coronavirus are expected to have a short-term influence until 2024. From that point onwards, climate change and smart shipping will be the catalysts for change. Therefore, the systems that are currently under development, including new fuels, such as ammonia $\left(\mathrm{NH}_{3}\right)$ and new power generation plants (e.g., fuel cells), are amongst the possible viable solutions to address these catalysts. 


\subsection{Emissions}

The shipping industry is accountable for a substantial part of global air pollution and the potential growth of seaborne transport can lead to an increase in carbon emissions [2]. Global shipping was responsible for more than 1 million tonnes of (Greenhouse Gas) GHG and $\mathrm{CO}_{2}$ emissions in 2018, indicating a significant increase of $9.6 \%$ and $9.3 \%$ respectively compared to the 2012 levels [3]. This leads to an increase in the share of shipping in the global anthropogenic emissions to the level of $2.89 \%$ [3]. Thus, in recent years, the shipping industry is facing great pressure to reduce environmental emissions and especially carbon emissions. This becomes even more important since it is forecasted that by 2050 carbon emissions could increase on a range of $80 \%$ to $130 \%$ compared to the 2008 levels [3]. In detail, by 2019 cruise ships emitted the most amount of $\mathrm{CO}_{2}$ per vessel ( 79000 tons per vessel per year), followed by Liquified Natural Gas (LNG) carriers ( 77000 tons per vessel per year). This highlights the increased effort required by the future designers and operators of these vessels. Similarly, on the same time-scale, Panama flagged vessels emitted the most amount of $\mathrm{CO}_{2}$ ( 117E6 tons), followed by Liberian ( 92E6 tons) and Marshall Islands ( 79E6 tons) flagged vessels [4]. This represents the increased importance that the flag states have in enforcing IMO regulations through their regulatory control.

\subsection{Regulations}

Due to the significant environmental impact of the shipping operations, the International Maritime Organisation (IMO) has imposed strict environmental regulations in the shipping industry. IMO has set the 2020 sulphur cap, which aims to decrease the sulphur global emissions to $0.5 \%$ compared to the previous level of $3.5 \%$. Additional regulations to reduce GHG emissions, like the Efficiency Design Index (EEDI), Energy Efficiency Operations Index (EEOI) and the Ship Energy Efficiency Management Plan (SEEMP) [5,6]. Along with these efforts towards decarbonisation, a reduction of $\mathrm{CO}_{2}$ emissions around $90 \%$ is required from 2010 to 2050 for the shipping industry to contribute to the global target of keeping the temperature increase below $2{ }^{\circ} \mathrm{C}$ [7]. The IMO Marine Environmental Protection Committee (MEPC), acknowledging the great contribution of the shipping sector to the global $\mathrm{CO}_{2}$ emissions, on 2018 set a target to reduce the $\mathrm{CO}_{2}$ emissions from the shipping sector by $50 \%$ until 2050 [8].

\subsection{Fuel Cells}

Fuel cells represent a feasible solution for the decarbonisation of the maritime industry. They exhibit improved energy density compared with batteries, and are less pollutant and more efficient than traditional internal combustion engines [9]. In addition, fuel cells can be powered with green fuels (hydrogen, ammonia) which further increases their potential. Fuel cells applications on the maritime sector have been gaining attention, and as reviewed by [9], fuel cell systems can be used to reduce the ship emissions. A comparative life cycle assessment analysis on fuel cells comparing them with traditional diesel generators was performed by [10] and by [11], where it was identified that a hydrogen operated fuel cells and batteries configuration is the most environmentally promising alternative compared to a diesel or a diesel hybrid system. The simulation of a hybrid system that includes Solid Oxide Fuel Cells (SOFC) was presented by [12] and by [13], with considerations the reduction of carbon emissions in the former and the EEDI, as well as the availability of the system in the latter. Furthermore, the design optimisation of a waste heat recovery technology combined with fuel cells for electric energy production was performed with technical and energetic considerations [14]. The synthesis and design optimisation of the integrated ship systems with focus on the SOFCs and economic, environmental, as well as energy efficiency objectives was developed by [15]. A hybrid system including photovoltaic system was proposed by [16]. Finally, the technical analysis of fuel cells, in order to improve the energy systems environmental performance was addressed by [17]. 


\subsection{Scope}

Furthermore, in the quest to reduce the global carbon footprint, reach a carbon-neutral human activity and adapt to the future environmental challenges, one of the main efforts is to introduce zero-emission fuels [18]. It is assumed that the targets set by IMO for 2050 will only be reached if carbon-neutral fuels provide $30-40 \%$ of the total energy [19]. Finding a carbon-neutral solution that is safe, innovative and commercially viable consists a major challenge for the maritime industry. A possible solution to this problem is to focus on alternative fuels with favourable environmental impact, whilst keeping in mind their availability, compatibility, cost and compliance with international rules (IGF and IGC Code) [20].

There are numerous options for alternative marine fuels, including hydrogen $\left(\mathrm{H}_{2}\right)$, alcohols (ethanol and methanol), Natural Gas (NG), biodiesel and $\mathrm{NH}_{3}$ [18]. However, none of the different options is a turn-key solution, as each potential application has different requirements and constraints. Among the possible alternatives, $\mathrm{NH}_{3}$ looks very promising since it has less complex and safer energy storage, compared to $\mathrm{H}_{2}$. It offers better energy density compared to $\mathrm{H}_{2}$, giving longer range and has a better environmental impact than NG. In addition, $\mathrm{NH}_{3}$ compared to other low carbon emission fuels is already produced in high quantities and transported around the globe, therefore it has established large-scale distribution infrastructures. An important issue when introducing a novel fuel is the power generation plant. $\mathrm{NH}_{3}$ is a flexible fuel that can be used both by the traditional marine engines and the more energy and environmental efficient fuel cells.

Large number of research studies have shown interest for ways to improve the environmental and carbon footprint of shipping by using zero-carbon fuels. Hydrogen has gained attention over the years, with various sources examining its potential as an energy vector $[21,22]$. In addition, the status-quo and existing issues of the hydrogen refuelling infrastructure has been discussed in various sources [23]. Authors have recently focused on ammonia, among them a review of the countermeasures to reduce the carbon emissions in shipping was performed in [24], where it is suggested among others that ammonia will be commercially viable alternative in the future. Others, presented an overview of the various hydrogen supply chains for the European ammonia production concluding that the production from electrolysis with non-fossil fuels has the highest overall emissions [25]. A review of the alternatives on the production and use of ammonia for hydrogen storage was presented [26]. However, there is a distinctive gap for a review discussing the advantages and challenges of ammonia-powered fuel cells for marine applications. Similarly, the topic of safe operations of ammonia-powered fuel cells has also not been thoroughly discussed, which is extremely important due to ammonia's particular safety characteristics. Therefore, this work reviews the state-of-the-art on ammonia-powered fuel cells in shipping, by also including safety considerations. To that extent, the impact of this work can be used by policymakers, technology developers, ship owners and designers to provide a datum for the development of regulations, operating practices and safe designs. For the remainder of the paper, Section 2 presents a critical review on alternative fuels, types of fuel cells and safety assessment options. Finally, Section 3 includes an overall discussion regarding the main outcomes and Section 4 condenses the conclusions of this work.

\section{Literature Review}

The review in this work is performed on three research areas, the applications of fuel cells in shipping, the use of ammonia as marine fuel and the safety assessment of ammonia use in shipping. The links of the research areas considered in this paper are presented in Figure 1. 


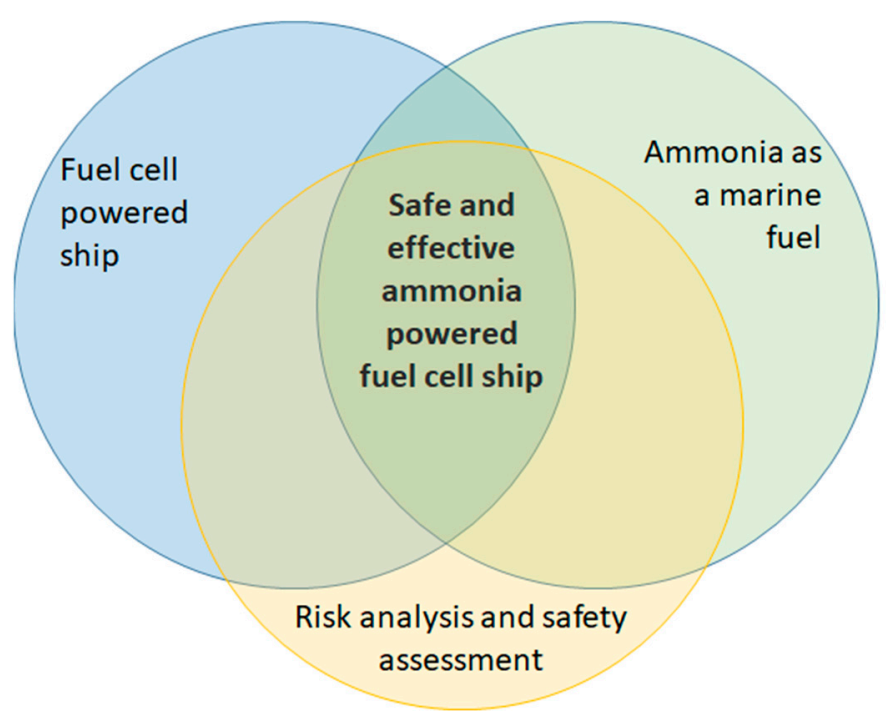

Figure 1. Research areas considered in this review.

\subsection{Alternative Fuels}

As previously mentioned, there are different alternative marine fuels available. As identified by Lloyd's Register \& UMAS in [27] and DNVGL in [28] the most viable options include hydrogen, ammonia, ethanol methanol, NG and methane. Biodiesel is not taken into consideration as it requires shipboard $\mathrm{CO}_{2}$ storage and related logistics which are time-consuming, complex and expensive to develop. The properties of the considered alternative fuels are shown in Table 1.

Table 1. Properties of alternative marine fuels.

\begin{tabular}{cccccc}
\hline Fuel & $\begin{array}{c}\text { Energy Density } \\
\text { LHV }(\mathbf{M J} / \mathbf{k g})\end{array}$ & $\begin{array}{c}\text { Volumetric Energy } \\
\text { Density }\left(\mathbf{G J} / \mathbf{m}^{3}\right)\end{array}$ & $\begin{array}{c}\text { Renewable Synthetic } \\
\text { Production Cost } \\
\mathbf{( M J} / \mathbf{M J})\end{array}$ & $\begin{array}{c}\text { Storage Pressure } \\
\text { (Bar) }\end{array}$ & $\begin{array}{c}\text { Liquified Storage } \\
\text { Temperature }\left({ }^{\circ} \mathbf{C}\right)\end{array}$ \\
\hline $\begin{array}{c}\text { Compressed } \\
\text { hydrogen }\end{array}$ & 120 & 4.7 & 1.7 & 700 & 20 \\
Liquid hydrogen & 120 & 8.5 & 1.8 & 1 & -253 \\
Ethanol & 26.7 & 21.1 & 3.6 & 1 & 20 \\
Methanol & 19.9 & 15.8 & 2.6 & 1 & 20 \\
Liquid methane & 50 & 23.4 & 1.8 & 1 or 10 & -162 \\
Liquid ammonia & 18.6 & 12.7 & & -34 or 20 \\
\hline
\end{tabular}

Currently, the most competitive alternative to traditional marine fuels is Natural Gas (NG) which consists of more than $90 \%$ of methane, therefore the same properties of liquid methane are considered for NG. NG has the highest volumetric density compared to the other fuels $\left(23.7 \mathrm{GJ} / \mathrm{m}^{3}\right)$. Engines operating with natural gas have reduced $\mathrm{NO}_{\mathrm{X}}$ emissions by $85-90 \%$ and almost zero Particulate Matter (PM) emissions. In addition, NG has zero sulphur content and very low carbon content. Dual fuel engines operating with NG are an established technology, however, due to the fossil fuel origin of NG, it is considered that it will serve only as a transitional fuel or as a precursor to the generation of ammonia [29].

Apart from NG, alcohols like methanol and ethanol can be considered as viable fuel alternatives since they both show high volumetric energy density $\left(15.8\right.$ and $21.1 \mathrm{GJ} / \mathrm{m}^{3}$, respectively). Methanol and ethanol can be produced from renewable sources and they appear as a promising substitute of marine fuel oils due to their high auto-ignition temperature and low viscosity [30]. In addition, they have negligible sulphur content, half of the NGs carbon content. Moreover, methanol operating marine engines have very low PM and $\mathrm{NO}_{\mathrm{X}}$ emissions [31]. However, due to the lower heating value of methanol (half of the NG), 
in order to have the same power output, the amount of fuel required is almost doubled compared to NG.

Hydrogen is a very attractive energy source with zero carbon emissions. It is produced from biomass, electrolysis and more often from NG, it is amply found in the universe, however hardly on its pure form [32]. It has low volumetric energy density, which leads to challenges in storing, hence, the storing technologies play an incremental role in the viable use of hydrogen in shipping [26]. Another limitation of hydrogen is that it has a low energy density $\left(4.7 \mathrm{GJ} / \mathrm{m}^{3}\right)$ in gaseous form compared to liquefied $\left(8.5 \mathrm{GJ} / \mathrm{m}^{3}\right)$, however, the liquefying process is energy consuming [22]. Hydrogen handling also causes serious concerns [33], due to the high flammability and the very low electro-conductivity rating [22]. Generally, there are safety issues regarding the fuel's volatility that need to be addressed [34] as well as the use of hydrogen in large merchant ships [19]. The successful deployment of hydrogen as a marine fuel suffers limitations also due to the high fuel price. Finally, there are insufficient bunkering infrastructures as well as there is a lack of standardised design and fuelling procedures [35].

Ammonia is also a zero carbon emissions fuel, which if it is derived from renewable sources, can play a significant role as a solution to store renewable energy [36]. Ammonia can be used in fuel cells as well as in ICE [34]. However, due to ammonia's high nitrogen content, its combustion in high temperatures leads to increased $\mathrm{NO}_{X}$ emissions [26]. Ammonia is a widely traded commodity produced in large quantities by the chemical industry, approximately 200 million metric tonnes per year [18] and it is mostly used for fertilisers. Thus, compared to hydrogen, there is an existing extended distribution network [36] as well as available port loading infrastructures and experience in handling [34]. Liquid ammonia has a higher energy density $\left(12.7 \mathrm{GJ} / \mathrm{m}^{3}\right)$ both from liquid and compressed hydrogen [37], which benefits the fuel storage. In general, the storage of ammonia is much less complex than hydrogen [38]. It is usually stored either refrigerated $\left(-34^{\circ} \mathrm{C}\right)$ or under pressure at ambient conditions $\left(20^{\circ} \mathrm{C}\right)$ [18]. Also, ammonia has a flexible utilisation since it can be used as a fuel itself, however, due to the high hydrogen density of approximately $17.8 \mathrm{wt} \%$, it could be used as hydrogen storage [26]. It is estimated that ammonia with a density of $653.1 \mathrm{~kg} / \mathrm{m}^{3}$ contains more hydrogen than a cubic meter of liquid hydrogen [39]. Therefore, this avoids the required cryogenic system necessary for the transportation of liquid hydrogen [40], which is very costly [32]. In addition, compared to hydrogen, ammonia is a more cost-efficient option due to both the lower price of the fuel [39] and the fact that there are already existing infrastructures.

Considering the above, a qualitative assessment of the alternative fuels together with an investigation of the relevant literature is necessary. From the discussed alternative fuels NG has the least potential as a long-term solution. This is caused by its uncompetitive characteristics, as it is prone to restrictions and higher prices. Moreover, from the alternative fuels, only methanol, hydrogen and ammonia can be produced from renewable electricity. And in more detail, only hydrogen and ammonia have the potential for zero net carbon emissions [27]. Similarly, it is observed, that ammonia and hydrogen have the lowest renewable synthetic production costs (Table 1 ). These are very important characteristics as they can influence the sustainability of the respective alternative fuel. From the above, and by also considering the insight from [28] ammonia and hydrogen are the two most promising alternative marine fuels.

For the following steps of the assessment, only hydrogen and ammonia are considered, due to their carbon-free emissions. To better understand their competitiveness, the Capital Expenditure (CAPEX) and Operating Expenditure (OPEX) of a hydrogen and ammonia power system is analysed. The CAPEX and OPEX of the two systems are also benchmarked against a traditional diesel system. In detail, the comparison is performed assuming a $2 \mathrm{MW}$ installation, an increasing $\mathrm{CO}_{2}$ tax [41], and a renewable electricity cost of $0.02 € / \mathrm{kWh}[42,43]$. Figure 2 shows the current, short-term and long-term (2030) CAPEX and OPEX for hydrogen and ammonia. As seen, the CAPEX for ammonia power system is slightly higher than hydrogen, however, it is predicted that this cost will decrease and 
reach a lower level than hydrogen. This behaviour is attributed to the increasing maturity of the technology and the comparatively reduced complexity of ammonia systems [44]. Similarly, the cost of ammonia fuel is predicted to decrease, owning to the maturity of the technology, with costs sustainably lower than hydrogen [45].

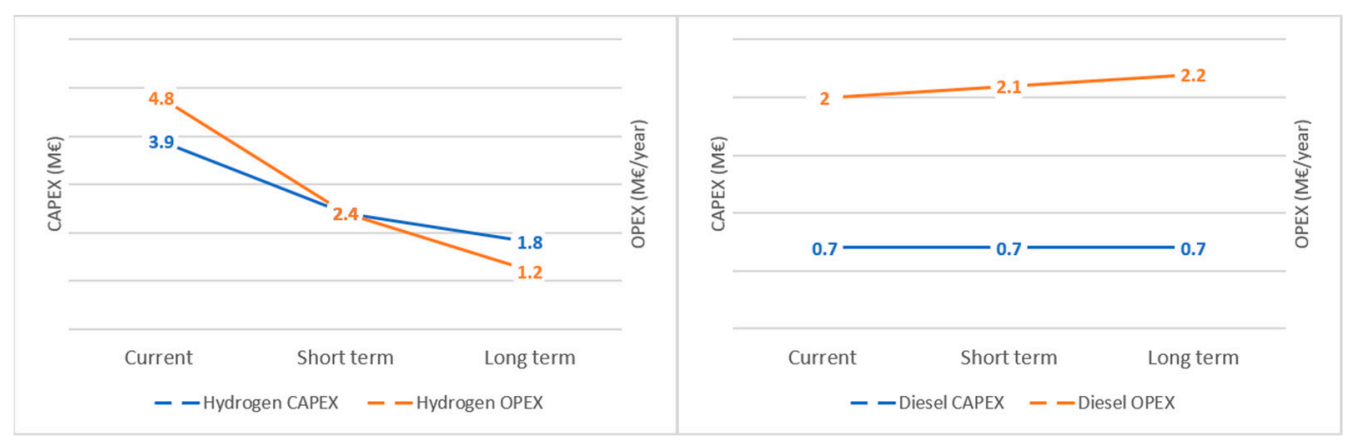

Figure 2. CAPEX and OPEX of hydrogen and ammonia system.

In a stark contrast with the aforementioned fuels, diesel powered systems face increased costs. The CAPEX on diesel powered systems is lower than the renewable counterparts, due to the maturity of the technology and the economies of scale. However, $\mathrm{CO}_{2}$ taxes and the IMO 2050 for decarbonisation will increase the cost of diesel fuel $[44,46]$. As a result, ammonia powered systems, are predicted to have the most favorable economic performance by 2030.

In addition, the largest benefit of ammonia as fuel, is that it is already a commonly traded commodity with established supply chains and availability in the proximity of ports globally. Therefore, even if the fuelling logistics must be worked out, the fuel prices can be expected to be lower than liquid hydrogen [47]. Also, due to ammonia's existing infrastructure, there are already regulations and protocols regarding its transportation and handling. Another major benefit of ammonia compared to hydrogen are its superior safety characteristics. In detail, ammonia is not flammable during storage and transportation [26]. Moreover, it can be dissolved in water [47] and gaseous ammonia can be dissipated in the air due to the low density, thus reducing the risk of fire as well as explosion [26]. Furthermore, even though ammonia is toxic, its strong odour helps in identifying leaks [32], mitigating hazardous situations. Lastly, as shown in Table 1, ammonia has a less complex storage and handling systems which reduces operating and purchasing costs.

In the existing literature, the use of ammonia in shipping has been discussed in a limited extent. The role of ammonia as a mean to store the excess renewable energy produced was investigated [33]. In the study, different technologies were assessed, and it was inferred that the combination of ammonia and battery was amongst the most profitable. Also, in [48] a Life Cycle Assessment analysis was performed in order to investigate the environmental impact of hydrogen and ammonia fuelled marine transportation tankers and ships, compared to traditional fuel oil. Results indicated that ammonia can be used for marine engines either as supplementary fuel or as a main fuel leading to significantly lower global warming during ship operation. A techno-economic investigation was performed considering different fuels, including ammonia, hydrogen, natural gas and methanol [27]. From the analysis it was derived that ammonia has the lowest total cost of operation compared to the other fuels. Finally, the potential role of ammonia in long distance shipping was examined and from the results it is concluded that it is a favourable option, however using as a main fuel for a tanker ammonia might have an impact on the increase of the total mass of the ship by a $2.74 \%$ to accommodate the changes required [49]. These changes represent the net effect of the removed mass of the relating to heavy fuel oil (e.g., settling tanks, purifiers, heats) and the additional mass associated with the increased space required for ammonia due to its reduced energy density compared to traditional 
hydrocarbons. Nonetheless, ammonia has a preferable space-to-energy trade-off compared to non-carbon emitting alternative fuels [45].

\subsection{Fuel Cells}

Apart from using alternative fuels, the IMO decarbonisation targets can be met through the research and implementation of alternative power generations plants. One of the options that is currently investigated is the batteries. However, studies indicate that batteries will face challenges in long-distance shipping due to their size, weight and price [49]. In addition, even though batteries are considered one of the most efficient energy storage technologies, the high cost and low energy density constitutes a limitation [33]. Thus, currently, batteries are not a viable option for primary energy supply in long-distance shipping. Fuel Cells (FCs) present an alternative, promising and innovative technology for electric energy production, which manages to reduce the emissions as well as the noise and improve the energy efficiency of ship energy systems [50]. They are electrochemical conversion devices that output electricity, heat and waste from the chemical reaction of inputs (e.g., air and fuel) [51]. FCs require a constant source of fuel to produce electricity, which is their differentiating factor from the energy storing batteries [52].

There are numerous FC systems for marine applications, which vary in terms of their proprietary technologies, system architecture and used fuels. The selection of the appropriate FC system is not a turn-key solution, as each implementation of FC in ships is application specific. This is because different FC systems have varying operating parameters and requirements. To that end, the choice of the FC system also influences the environmental impact of the system, the hazards of the system and the operating economics [53].

In detail, there are five main FC types applicable to the maritime industry. These are the Low Temperature Polymer Electrolyte Membrane FC (LT-PEMFC), High Temperature Polymer Electrolyte Membrane FC (HT-PEMFC), Phosphoric Acid FC (PAFC), Molten Carbon FC (MCFC) and Solid Oxide FC (SOFC) [51]. LT-PEMFC can deliver high power density, have efficiency of up to $60 \%$ and can be directly fed with pure hydrogen [54]. They operate between $65-85{ }^{\circ} \mathrm{C}$ (low start-up, high durability), but have less tolerance to fuel impurities [55]. HT-PEMFC have an operating temperature envelope ranging between $120-180{ }^{\circ} \mathrm{C}$ [56] and electrical efficiency of up to $60 \%$ [54]. Also, HT-PEMFC require additional time to start-up and have a higher tolerance to fuel impurities [55]. PAFC operate at around $150-200{ }^{\circ} \mathrm{C}$ and have similar durability and start-up characteristics as HT-PEMFC However, they have low power density, limited durability, $40 \%$ electrical efficiency [54] have restricted their commercial shipping applications [57]. MCFCs are often used for large-scale power generation [58] due to their good power density and up to $50 \%$ electrical efficiency [54]. They operate between $700-800{ }^{\circ} \mathrm{C}$ (limited durability) which allows for the recovery of waste heat from the water. Lastly, SOFC operate between $700-1000{ }^{\circ} \mathrm{C}$ (low durability, high start-up) [59] and they can achieve very high power densities [51] and up to $60 \%$ electrical efficiency [54]. SOFC can be directly fed with $\mathrm{NH}_{3}$ as fuel and as such, they are deemed by the wider community as a promising candidate for sustainable energy conversion [60].

The discussed characteristics of the examined FCs are summarized in Table 2. As seen, the FC systems are evaluated in terms of their operating temperatures, durability, startup time, Capital Expenditure (CAPEX), power density and electrical efficiency; criteria distilled from the work of [51,52]. It is observed that SOFC have very good power density and electrical efficiency. Also, due to their high operating temperature, they have simpler fuel feed systems as fuel (e.g., $\mathrm{NH}_{3}$ ) can be supplied directly without any pre-treatment. SOFC are ideal candidates for hybrid electric systems, and especially for larger vessels [61]. Due these advantages, SOFC for maritime applications have seen increased development. 
Table 2. FC types comparison.

\begin{tabular}{|c|c|c|c|c|c|}
\hline & LT-PEMFC & HT-PEMFC & PAFC & MCFC & SOFC \\
\hline Operating Temperature $\left({ }^{\circ} \mathrm{C}\right)$ & $65-85$ & $120-180$ & $150-200$ & $700-800$ & 700-1000 \\
\hline Durability & High & Medium & Medium & Low & Low \\
\hline Start-up Time & Low & Medium & Medium & High & Very High \\
\hline CAPEX & High & Medium & High & Low & Medium \\
\hline Complexity & High & Medium & Medium & Medium & Low \\
\hline Power Density & Medium & Medium & Low & High & Very High \\
\hline Electrical Efficiency (\%) & 60 & 60 & 40 & 50 & 60 \\
\hline
\end{tabular}

\subsubsection{Ammonia Fuel Cells}

From the preceding discussion it is inferred that ammonia is a promising energy carrier with merits regarding the environmental footprint, production, and transportation, while avoiding the challenges associated with hydrogen. In this section, a review of the application and techniques of ammonia powered fuel cells is presented.

In the existing literature there has been great attention on potential catalysts for the ammonia oxidation [62-65] and specifically for SOFCs [66,67]. The performance of ammonia fuel cell for land-based energy production or for other systems has attracted attention in the literature, as presented in Table 3. Three different operation modes, direct ammonia supply, external decomposition supply and autothermal decomposition supply, of the ammonia SOFC performance were investigated and the stability of the stack was evaluated for up to $1000 \mathrm{~h}$ in $[66,68]$ indicating no significant degradation. A direct ammonia FC was investigated and the results indicate that a high peak power density can be used when using an ammonia-tolerant catalysts [69]. An integrated system that recovers waste heat from an ammonia molten alkaline fuel cell was proposed and investigated to meet the different energy demands of a passenger railway transportation, concluding to improved efficiency of the system and zero carbon emissions [70]. In [47] it was demonstrated that ammonia can be used directly on SOFC as the sole source of hydrogen. The results indicated that the performance of the ammonia powered SOFCs were similar to the one operating solely with hydrogen. Two alternative hydrogen carriers, biogas and ammonia, were examined as a potential fuel of SOFCs, achieving high efficiencies and stability [71].

The performance and durability investigation of an ammonia powered solid oxide fuel cell stack was presented in [72] indicating amongst others that ammonia is a promising fuel for SOFCs. The SOFC operation with ammonia was compared in the same conditions with using hydrogen and results in the nominal conditions indicated the same degradation in both cases, also with no detection of ammonia on the off gasses or significant nitrification of anode [36]. Similar results were found on other studies, it was also indicated that no severe deterioration was recognised after a long operating period [73]. The exergy and energy performance of ammonia fuel cells was investigated in $[74,75]$ and the potential of using a blend of ammonia and hydrogen was considered in [74], it can be inferred from the results that the mixture of the two fuels improves the efficiency of the fuel cells. The feasibility of ammonia combined use with biomethane in an internal reforming SOFC was presented in [76] and the overall system demonstrated an efficiency of $48 \%$.

Furthermore, the potential of ammonia powered fuel cells in shipping has been also investigated in the studies presented in Table 3. An economic and environmental comparative assessment of an innovative ammonia powered system with the traditional power systems on a container feeder ship was performed in [32]. The results indicated that ammonia could lead to a carbon-free shipping operation, however, even though SOFC is the most environmentally friendly technology, it experiences a high life cycle cost. 
Table 3. Ammonia powered fuel cells.

\begin{tabular}{|c|c|c|c|c|}
\hline Source & \multicolumn{2}{|c|}{ Fuels } & Power Plant & Technology \\
\hline$[67,69]$ & \multicolumn{2}{|c|}{ Ammonia } & Land-based & SOFC \\
\hline$[70]$ & \multicolumn{2}{|c|}{ Ammonia } & Vehicle & Direct FC \\
\hline$[71]$ & \multicolumn{2}{|c|}{ Ammonia } & Railway & $\begin{array}{l}\text { Molten alkaline fuel } \\
\text { cell }\end{array}$ \\
\hline$[36,74]$ & Ammonia & Hydrogen & Land-based & SOFC \\
\hline$[77]$ & Ammonia & Biomethane & Land-based & SOFC \\
\hline [75] & Ammonia & Hydrogen & & Alkaline fuel cells \\
\hline [72] & Ammonia & Biogas & Land-based & SOFC \\
\hline [76] & \multicolumn{2}{|c|}{ Ammonia } & vehicle & SOFC \\
\hline [32] & Ammonia & $\mathrm{HFO}$ & Container ship & $\begin{array}{c}\text { SOFC } \\
\text { PEMFC } \\
\text { Diesel engine } \\
\text { Diesel electric }\end{array}$ \\
\hline [73] & Ammonia & hydrogen & Land-based & SOFC \\
\hline [48] & Ammonia & hydrogen & Land-based & SOFC \\
\hline
\end{tabular}

\subsubsection{Future Perspectives and Challenges of Ammonia Fuel Cells}

As previously discussed, ammonia is a flexible fuel and it can be used in different technologies however, fuel cells appear the most promising. It is argued that ammonia operating fuel cells have higher efficiencies and emit less noise than the conventional engines [37]. It should also be noted that when ammonia is used by traditional energy systems, such as diesel engines it requires a pilot fuel, thus leading to $\mathrm{NO}_{\mathrm{X}}$ emissions, compared to FCs $[36,77]$. Therefore, fuel cells are the most efficient technology to extract energy from ammonia.

However, different challenges are identified for the various FCs types. It is supported that for the low temperature FCs such as the PEM, it is challenging for the catalytic to produce hydrogen from ammonia in the low temperatures [78], whereas SOFCs are preferred due to the fact that they do not require 'ammonia cracking' [50]. PEMFCs with acidic membrane are not compatible with ammonia and a cracking reactor is necessary [79], which can occupy a high volume and has high cost [80], otherwise the electrolysis would require energy produced by the FCs, thus decreasing their efficiency [79]. Regarding the membrane-based fuel cells a major limitation considered is the conductivity and stability of alkaline exchanged membrane, however this type of FCs has not been widely explored for ammonia fuel [81].

On the other hand, ammonia can be used directly on SOFC, compared to PEM that require prior ammonia to be split into hydrogen and $\mathrm{N}_{2}$ and then be used [37]. During the SOFC operation, ammonia is decomposed in the anode of the fuel cells thus leading to hydrogen production, which then has an electrochemical reaction that leads to power production [36]. Regarding the ammonia powered SOFCs one of the main challenges is the robust redox reaction in the anode of fuel cells, this could improve the durability to sustain the temperature changes and avoid formation of nitrides [78]. Furthermore, SOFCs are criticised due to the low start-up time [80], therefore an integrated system is required that it will include a battery. An advantage of the SOFCs is the fact that they employ zirconia-based electrolytes, which have a high chemical and thermal stability in the ammonia atmosphere $[66,81]$.

It is evident that various concerns and challenges arise for ammonia fuel cells regarding the compatibility of ammonia and the high temperatures required for the ammonia cracking with the electrolytes [78]. Furthermore, the choice of catalyst at the anode is crucial and it requires to have a high selectivity on $\mathrm{N}_{2}$ [81]. Another concern regarding the low-temperature FCs is to reduce the ammonia cross-over which is often caused due to the thinner membrane [81]. A review of the ammonia fuel cells regarding these issues was performed in [81], concluding that SOFCs is currently the most promising technology. However, development is required for commercially available ammonia fed SOFCs [82]. 
From the analysis, it is evident that there are technological barriers that need to be addressed before using ammonia FCs. Existing studies and projects have demonstrated the feasibility of SOFCs onboard ships as it can be seen in $[83,84]$, highlighting the benefits of SOFCs regarding the excess heat utilisation due to the high operating temperatures. However, all the demonstrations were on small scales and capacities, therefore, one of the issues that needs to be addressed when considering FCs for large-scale ocean-going vessels are the weight and volume limitations. Even though, FCs are modular and can be arranged on stacks in order to reach the required power demand and scaling up the number of stacks does not impact the FCs efficiency. In addition, there are studies that predict that moving towards higher maturity, FCs will achieve a high volumetric power density, higher than the traditional diesel engines [85]. Another concern regarding utilisation on commercial vessels is the cost of FCs and the emerging fuel, such as ammonia. As it is evident from Figures 2 and 3, despite having currently a high cost, it is predicted that the cost will decrease, as a consequence of the maturing technology.

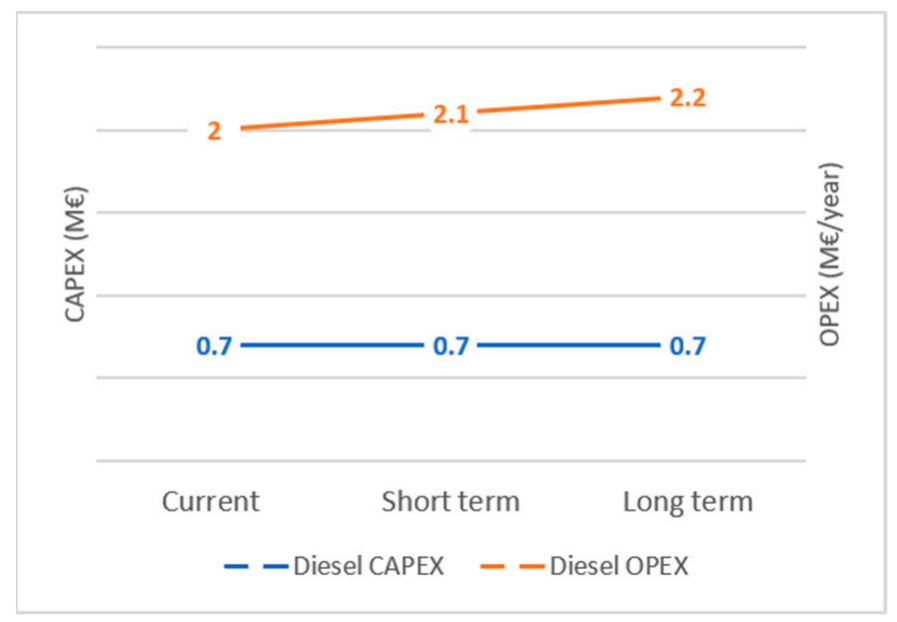

Figure 3. CAPEX and OPEX of diesel system.

Finally, another challenge that needs to be addressed is the regulatory framework establishment both for the FCs and ammonia. Currently, there is a number of international regulations ensuring the safety of ammonia transport on ships, such as the International Code for the Construction and Equipment of Ships Carrying Dangerous Chemicals in Bulk, the International Code for the Construction and Equipment of Ships Carrying Liquefied Gases in Bulk and the International Code of the Construction and Equipment of Ships Carrying Liquefied Gases in Bulk (IGC Code). However, for the use of ammonia as a fuel in shipping, the only relevant regulation is the IGF Code-International Code of Safety for Ships Using Gases or Other Low-Flashpoint Fuels, which was adapted on 2017 only for natural gas and for internal combustion engines, boilers and gas turbines [83]. Therefore, amendments on the IGF Code are required specifically for the use of ammonia as a fuel for ships. TNO has also published guidelines for the quantitative risk assessment and leak frequency models [86], methods for the calculation of physical effects due to releases of hazardous materials (liquids and gases) [87] and methods for the determination of possible damage to people and objects resulting from releases of hazardous materials [88]. Unfortunately, they are providing guidelines for land-based facilities, therefore there is a need to adapt these models and methods to shipping. Finally, regarding the FCs installation onboard ships, there are rules for classification with the technical requirements [89], but due to the differences between the various FCs types, the technical provisions should consider the different technologies [83]. It is highlighted that further gas dispersion and safety studies are necessary in order to identify hazardous zones and safety distances [83]. 


\subsection{Safety and Reliability}

Reliability Assessment (RA) tools are extensively used to analyse the risk, safety and reliability of systems. They are typically used during the design of systems to ensure their safety and reliability, under the requirements of the Technology Qualification (TQ) process and in order to comply with the IMO Alternative Design Regulations [90]. These tools are also employed during the development of novel systems to ensure that the risks of new technologies are appropriately managed and mitigated. Therefore, the development of an ammonia fuel cell for power generation in long-haul shipping represents a typical example for the application of RA tools.

\subsubsection{Risk Assessment Methods}

Using RA tools is an expected process when developing new systems, such as $\mathrm{NH}_{3}$ powered FCs. Commonly, RA tools can be classified as qualitative or quantitative and as top-down or bottom-up approaches. Qualitative RA tools address the issues of risk, reliability and safety descriptively, whereas quantitative RA tools try to quantify these issues numerically. Similarly, top-down tools, focus on the broader context of risk, safety and reliability by analysing the causes of specific events. On the other hand, bottomup approaches examine the behaviour of a system subjected to disturbances. The most common RA tools include Fault Tree Analysis (FTA), Bayesian Networks (BN), Failure Modes Event Analysis (FMEA), Failure Modes Event and Criticality Analysis (FMECA) and Event Tree Analysis (ETA).

FTA utilizes logic-gates and events to represent an engineering system (e.g., $\mathrm{NH}_{3}$ fuel supply system) and to create a visual model with interconnected pathways that can lead to an undesirable failure within the system [91]. The logic-gates simulate the functional dependencies within the examined system. On the other hand, events are used to model components, and they are located at the lower level of the system's model architecture. The events are also used to quantify the Fault Tree, as they require the input of failure statistics (e.g., failure rate, probability of failure) for each component (e.g., $\mathrm{NH}_{3}$ pump) [92]. FTA is a top-down approach and initiates by stating an undesirable event (e.g., failure of $\mathrm{NH}_{3}$ heater) [93].

Bayesian Networks $(\mathrm{BN})$ is a popular RA tool that traces their origin in computer science, where they were developed in 1985 by Judea Pearl [94,95]. BNs are probabilistic Directed Acyclic Graphical (DAG) models that depict functional and causal dependencies between random variables [96]. Like FTA, BN consist of a qualitative part and a quantitative part. The qualitative part is defined by a DAG model where each variable is depicted as a node. The qualitative part includes also directed links between the nodes to define causal relationships and functional dependencies. Similarly, the quantitative part is defined by the conditional probability distribution in the Conditional Probability Table (CPT) of each node (variable). Due to the causal dependencies, BNs are widely used for diagnostic tasks [97,98], reliability calculations and for modelling complex systems.

FMEA and FMECA are two very similar RA tools that are widely used in many different sectors [99] among others to perform a reliability analysis on fuel cells [100]. FMEA and FMECA can be used to control risk by foresing possible failures during the design of a system, by identifying all the potential failure modes [101]. The main philosophy of these two RA tools is the anticipation and prevention of failures in a system by examining the different ways a system can fail [102]. FMEA can be considered as a qualitative tool, which is developed by using chained "what-if ?" questions [103,104]. On the other hand, FMECA is quantitative as it tries to quantify the criticality of each failure, caused by the different hazards. In other words, FMEA can be performed first, and after a criticality analysis through FMECA can follow [105]. Both FMEA and FMECA are widely applicable tools, as they provide a structured approach to reliability improvement and risk control [101]. These tools address in detail the technical issues of the examined system, provide a starting point for mitigating risk [106]. 
Event Tree Analysis (ETA) is a popular RA tool that examines the possible outcomes in a system resulting from an initiating event, usually a failure [99]. ETA is often used to identify the potential chains of events and resulting outcomes by examining the response of a system to a disturbance [107]. For instance, ETA can be used to examine the outcomes to the vessel of the failure of the FC. ETA is a quantitative approach and requires the input of failure statistics, to assess, through binary logic, the probabilities of different possible outcomes [108]. In more detail, each of the different events are represented in individual branches that also include the probability of the different events. ETA is performed sequentially and initiates by stating an examined event (e.g., FC failure). The consequences of the initiating event are examined through a series of different outcomes, with each different outcome represented in its branch $[109,110]$. Completing an ETA results in quantified chains of events with computed probabilities for the different branches. ETA is instrumental in modelling successive events and analysing the propagation of hazards $[109,111]$.

The main goal of this section is to complete a qualitative assessment of the RA tools, in order to give an insight on the selection process during the assessment of novel technologies (e.g., $\mathrm{NH}_{3} \mathrm{FCs}$ ). The RA tools are assessed against five criteria, which were identified in the previous sections. More specifically, the used criteria include how well-established and flexible each tool is, the different applications of each tool and the ability to model functional dependencies and sophisticated systems. In detail, the flexible criterion examines the ability of each tool to be used in both qualitative and quantitative manners. Also, the applications criterion assesses the variety of applications each tool can be used. The functional dependencies criterion explores the ability of each tool to model systems with intricately interconnected components. Lastly, the complex systems criterion considers the ability of each tool to model complex systems by also incorporating information from different sources (i.e., sensor fusion).

Figure 4 shows the performance of the examined RA tools against the distilled criteria from the previous sections. FTA is a well-established tool with high flexibility, as it can be used for both qualitative and quantitative tasks. It can be used in several sectors; however, it is usually restricted with reliability-related tasks (e.g., reliability analysis, criticality analysis). FTA is also limited in its ability to model functional dependencies in examined systems. Lastly, FTA can model complex systems and could use information from different sensors. Similarly, BNs are well established; however, they are not suitable for quantitative analysis. BNs can be used in many applications, and they can also model functional dependencies effectively. Lastly, BNs are suitable for modelling complex systems and are very good at integrating information from different sources. FMEA and FMECA are also well-established tools which can be used both for qualitative and quantitative purposes. These tools are limited to reliability analysis and cannot model functional dependencies. Lastly, FMEA and FMECA can model complex systems; however, the process of doing that can be time consuming. ETA is also a very well-established RA tool. Its flexibility is limited to only quantitative analysis; however, the structure of the Event Tree may give a rudimentary understanding of the chain of causality. ETA is limited in its applications, with most examples from the areas of accidents investigations and reliability analysis. Lastly, ETA cannot model complex systems and situations, as the resulting Event Tree can become too complex. 


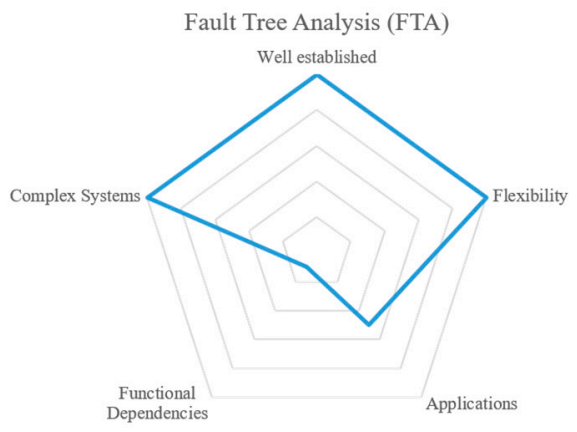

Failure Modes Event Analysis (FMEA) and Failure Modes Event and Criticality Analysis (FMECA)

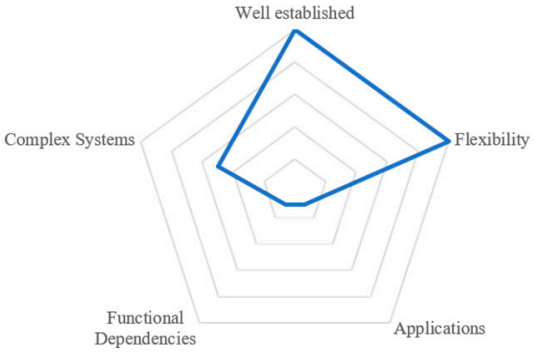

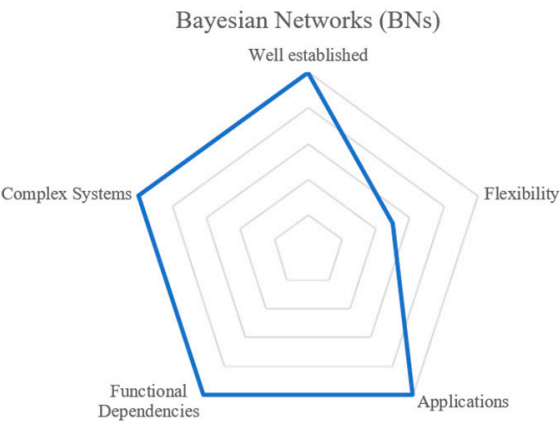

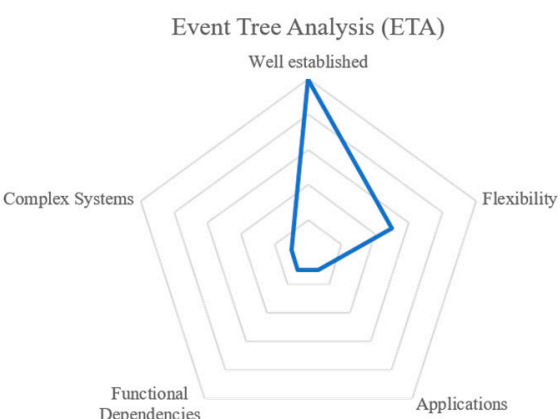

Figure 4. Research areas considered in this review.

\subsubsection{Ammonia Fuel Cells Safety in Shipping}

Although, the stable state of pure $\mathrm{NH}_{3}$ at environmental conditions is the gas phase, efficient ammonia storage and transport require the use of liquid anhydrous $\mathrm{NH}_{3}$. For a stable liquid state, pure anhydrous $\mathrm{NH}_{3}$ can either be cooled down to $-33^{\circ} \mathrm{C}$, or pressurized above its vapor pressure. When pure $\mathrm{NH}_{3}$ is released into the environment, it will disperse in a variety of forms including mixing with air $[112,113]$. Furthermore, depending on the release conditions and the chemical constitution of the surroundings, dispersion of $\mathrm{NH}_{3}$ can participate in a variety of physical and chemical processes including, releasing significant amount of heat due to exothermic dissolution and corrosion of metals [114].

Due to the widespread use of $\mathrm{NH}_{3}$ in chemical applications, a good amount of knowledge is available for both its chemical properties and potential hazards. In detail, $\mathrm{NH}_{3}$ is flammable but with a high ignition temperature [115], and as such, its vapours are not considered as a fire hazard [116]. Upon ignition, $\mathrm{NH}_{3}$ vapours can also result into explosions in concentrations between $15 \%$ and $28 \%$. Further hazards related to $\mathrm{NH}_{3}$ vapours include irritation and burns to the eyes, skin, at respiratory tract, whereas timely exposure to high concentration, (about $20 \mathrm{~min}$ in concentrations $0.5 \%$ ), can result in serious injury or even prove lethal for humans. Estimation on the concentration that result in $50 \%$ mortality (LC50) have been made possible via studies in animals, where of example $50 \%$ of the rats did not survive $10 \mathrm{~min}$ exposure at concentrations of 40,300 ppm [20]. A positive aspect related to $\mathrm{NH}_{3}$ releases is that its pure vapor has a significantly lower density compared to air, by about $30 \%$. As a result, the $\mathrm{NH}_{3}$ vapours initially formed during a release, are expected to disperse in an upwards direction, dispersing into higher levels.

In summary, the main issues that should be considered when handling and transporting ammonia are its flammability and toxicity. Despite this, ammonia is much less flammable and explosive than either hydrogen or methane and its ignition temperature is much greater than both. On the other hand, the high toxicity of ammonia poses a serious threat. Acute Exposure Guideline Levels (AEGLs) have been defined for ammonia, representing the threshold of exposure (time of exposure and concentration of ammonia) and the repercussions. Three levels are identified and are presented in Table 4 
Table 4. Ammonia exposure levels by National Research Council (2007).

\begin{tabular}{|c|c|c|c|c|}
\hline \multirow[t]{2}{*}{ Level } & \multicolumn{3}{|c|}{ Exposure Time } & \multirow[t]{2}{*}{ Repercussion } \\
\hline & $10 \mathrm{~min}$ & $30 \mathrm{~min}$ & $60 \mathrm{~min}$ & \\
\hline AEGL-1 & $30 \mathrm{ppm}$ & 30 ppm & 30 ppm & $\begin{array}{l}\text { 'discomfort, irritation, or } \\
\text { asymptomatic } \\
\text { nonsensory effects' }\end{array}$ \\
\hline AEGL-2 & 220 ppm & 220 ppm & $160 \mathrm{ppm}$ & $\begin{array}{c}\text { 'irreversible or other serious, } \\
\text { long-lasting adverse health } \\
\text { effects or an impaired ability } \\
\text { to escape' }\end{array}$ \\
\hline AEGL-3 & $2700 \mathrm{ppm}$ & $1600 \mathrm{ppm}$ & 1100 ppm & $\begin{array}{l}\text { 'life-threatening health effects } \\
\text { or death' }\end{array}$ \\
\hline
\end{tabular}

Another concern is the fact that when ammonia is mixed with water it becomes highly corrosive, however, the use of stainless steel and iron protects from corrosiveness. The hydraulic shocks, due to the high heat of vaporisation of ammonia as well as the expansion when boiling could be also a fear [18]. On the other hand, the Rapid Phase Transition (RPT) is not expected to be an alarming issue, due to the solubility of ammonia in water, the low difference of the temperature between the two liquids and finally the fuel's high heat of vaporisation [18].

Experimental research within ammonia safety is mostly related to release and dispersion and less regarding its explosion properties, as this risk is secondary. Details of experiments performed are discussed in [18]. In general, the fatal accidents caused by ammonia are very few [116]. More specifically, ship accidents were investigated using the Sea-Web database (IHS Markit) and 'ammonia' as a keyword. The results from the database are depicted in Table 5. It is evident that the majority of accidents are on fishing vessels where ammonia is used for refrigeration purposed. The search revealed only one case on a containership where there was ammonia leakage as a cargo. Due to the toxicity of ammonia, in most cases there were fatalities associated with its release while the impact to the environment was negligible. Yet, the quantities carried where much less that those needed when ammonia will be used as a fuel.

Table 5. Ship accidents related to ammonia.

\begin{tabular}{|c|c|c|c|c|}
\hline \multirow{2}{*}{ SHIP Type } & \multirow{2}{*}{ Event } & \multirow{2}{*}{ Accident } & \multicolumn{2}{|c|}{ Consequences } \\
\hline & & & Personnel Safety & Environment \\
\hline Container & Hull/Machinery Damage & Leak of ammonia cargo & None & None \\
\hline Fishing vessel & Hull/Machinery Damage & $\begin{array}{l}\text { Ammonia leak in } \\
\text { refrigeration }\end{array}$ & Fatalities & None \\
\hline Fishing vessel & Hull/Machinery Damage & $\begin{array}{l}\text { Explosion in engine room } \\
\text { following rapture of } \\
\text { ammonia storage }\end{array}$ & Fatalities & None \\
\hline Fishing vessel & Hull/Machinery Damage & $\begin{array}{l}\text { Ammonia leak after burst } \\
\text { of refrigeration pipe }\end{array}$ & Fatalities & None \\
\hline
\end{tabular}

Taking the above into consideration, the safety concerns of shipboard $\mathrm{NH}_{3}$-fuelled FC power generation systems must be discussed. As mentioned, the risk of ammonia pool fires is relatively low, as they are restricted by a high ignition temperature. Similarly, the risk of jet fires is also minimum, and the risk of explosions is controlled by a narrow explosion limit window. In addition, the quantities of ammonia required to cause explosions are not feasible under the context of ship propulsion. Consequently, the main hazards associated with $\mathrm{NH}_{3}$ fuel for FCs concern its toxicity and corrosiveness. In detail, the release of liquid $\mathrm{NH}_{3}$ during bunkering operations, at the vessel's bunkering connection, is a major hazard. Such a release can damage surrounding structures, and harm crew members supervising the bunkering operation $[117,118]$. As a result, to mitigate such a hazard the bunkering 
equipment of the ship must be thoroughly inspected, and proper operating practices must be developed, which is currently outside of the scope of this paper [23]. Another hazard associated with the discussed system is the leak of $\mathrm{NH}_{3}$ vapour close to the FCs. This is caused by the increased pressure of $\mathrm{NH}_{3}$ prior to its use in FCs and the confined areas close to the FC stacks. As a result, released vapours can get trapped resulting in hazardous areas. Measures including case-specific dispersion studies can be used to mitigate this hazards, together with increased inspection and maintenance schemes [119].

\section{Discussion}

Currently, there is an urgent need to develop a feasible approach to comply with the IMO global strategy and the Paris agreement, to reduce shipping's greenhouse gas emissions. In this work, the possibility to employ ammonia powered fuel cells towards the quest of decarbonising shipping is reviewed, along with the safety issues that should be considered. In this section, the main challenges of ammonia playing a leading role towards achieving the IMO 2050 targets are discussed.

In general, despite the environmental benefits of ammonia as a marine fuel, there is a lack of commercial ammonia powered marine technologies [37]. MAN Energy solutions recently proposed that the developed dual-fuel engine operating with LPG could be set up to operate with ammonia [38]. This technology is investigated from MAN Energy solutions, Shanghai Merchant Ship Design \& Research Institute and American Bureau of Shipping for an ammonia-fuelled feeder container. Still, as it was previously highlighted, the combustion of engines in high temperatures operating with ammonia might lead to increased $\mathrm{NO}_{X}$ emissions, thus a Selective Catalytic Reactor would potentially be needed.

From the preceding analysis it can be inferred that despite the benefits of ammonia powered fuel cells and the fact that it is a proven feasible solution in small scale operation in shipping, it has never been implemented in a large-scale ship power system. Recently projects have started working on developing ammonia powered SOFCs to be installed on a cruise vessel (Clean Ammonia Power CAP, supported by Innovation Norway) or to develop a feasible approach for large-scale carbon emissions reduction for international shipping, by investigating and retrofitting a vessel totally powered by a $2 \mathrm{MW}$ ammonia SOFC.

An issue that arises with the use of ammonia in shipping is the need for large-scale production infrastructures for green or blue ammonia. The former is produced by renewable energy while the latter by fossil fuel sources with carbon capture and storage technology. It should be noted that in order for ammonia to satisfy the needs of international shipping fleet, more than 650 million tonnes of ammonia would be needed, which corresponds to 6500TWh of renewably produced electricity [120]. Nevertheless, since ammonia is used for many other applications, such as fertilisers, it is already produced in large quantities; these industries are already making considerable efforts to produce green ammonia using electrolysis at reasonable costs.

Finally, there are reports regarding the use of ammonia in land-based facilities providing guidelines for the risk assessment and models to estimate the leak frequencies or the physical effects and possible damage to people due to release. Experimental investigations of ammonia releases on solid ground include the Desert Tortoise experiments [121], the FLADIS experiments [122] and the Jack Rabbit-I experiments [122], all large scale tests involving continuous flashing jet releases without any obstructions and pool formation in the case of Jack Rabbit tests. However, there is a gap in similar guidelines in shipping. The existing regulations in shipping IGF focuses in general in the safety use of gases but does not provide specific details for ammonia. Therefore, it is imperative for the largescale application of ammonia as main fuel in shipping to amend the IGF Code and adopt guidelines specifically for its use.

\section{Conclusions}

The challenge of developing viable solutions to reduce the greenhouse gas emissions in large scale in shipping is reflected in public policy on national, European and a global 
level. A state-of-the-art review was performed to discuss the current status of ammonia in shipping, along with the potential and challenges of ammonia having an imperative role in the decarbonisation in shipping. From the analysis it is inferred that one of the main challenges for ammonia as a marine fuel is the lack of a commercial technology. Furthermore, it was concluded that it is imperative to develop large-scale production infrastructures for green or blue ammonia. Similarly, based on the potential of $\mathrm{NH}_{3}$ fuel for future widespread use, especially in marine applications, there is a need for knowledge development. In detail, there is a clear need for the identification of the hazards and consequences of $\mathrm{NH}_{3}$ release through various dispersion studies. To that end, physical release experiments and simulation-based studies are required. Finally, and as also discussed in the paper, regulations and guidelines must be developed in parallel with the knowledge development.

Funding: This work was partially supported by the "ShipFC" project. The ShipFC project has received funding from the Fuel Cells and Hydrogen Joint Undertaking under grant agreement No 875156. This Joint Undertaking receives support from the European Union's Horizon 2020 research and innovation program and from Hydrogen Europe.

Acknowledgments: This work was partially supported by the "ShipFC" project. The ShipFC project has received funding from the Fuel Cells and Hydrogen Joint Undertaking under grant agreement No 875156. This Joint Undertaking receives support from the European Union's Horizon 2020 research and innovation program and from Hydrogen Europe. Boulougouris, Theotokatos, Triviza and Cheliotis greatly acknowledge the funding from DNV GL and RCCL for the MSRC establishment and operation. The opinions expressed herein are those of the authors and should not be construed to reflect the views of DNV GL and RCCL.

Conflicts of Interest: The authors declare no conflict of interest.

\section{References}

1. Abbasi, R.; Setzler, B.P.; Wang, J.; Zhao, Y.; Wang, T.; Gottesfeld, S.; Yan, Y. Low-temperature direct ammonia fuel cells: Recent developments and remaining challenges. Curr. Opin. Electrochem. 2020, 21, 335-344. [CrossRef]

2. Abdin, Z.; Zafaranloo, A.; Rafiee, A.; Mérida, W.; Lipiński, W.; Khalilpour, K.R. Hydrogen as an energy vector. Renew. Sustain. Energy Rev. 2020, 120, 109620. [CrossRef]

3. ABS. Setting the Course to Low Carbon Shipping. 2019. Available online: https://absinfo.eagle.org/acton/attachment/ 16130/f-982b1623-4d26-4b04-91c5-25453a6e2fba/1/-/-/-/-/low-carbon-shipping-outlook.pdf?utm_term=DOWNLOAD\& utm_campaign=2019LowCarbonShippingOutlook\&utm_content=email\&utm_source=Act-On+Software\&utm_medium=email (accessed on 15 April 2021).

4. Ahn, J.; Park, S.H.; Noh, Y.; Choi, B.I.; Ryu, J.; Chang, D.; Brendstrup, K.L.M. Performance and availability of a marine generator-solid oxide fuel cell-gas turbine hybrid system in a very large ethane carrier. J. Power Sources 2018, 399, $199-206$. [CrossRef]

5. Al-Hamed, K.H.M.; Dincer, I. A novel ammonia molten alkaline fuel cell based integrated powering system for clean rail transportation. Energy 2020, 201, 117620. [CrossRef]

6. Alkaner, S.; Zhou, P. A comparative study on life cycle analysis of molten carbon fuel cells and diesel engines for marine application. J. Power Sources 2006, 158, 188-199. [CrossRef]

7. Anderson, K.; Bows, A. Executing a Scharnow turn: Reconciling shipping emissions with international commitments on climate change. Carbon Manag. 2012, 3, 615-628. [CrossRef]

8. Anderson, M.K. Ammonia safety, a global perspective. In Proceedings of the Technion Ammonia Conference, 29 October3 November 2017; Available online: http://chemeng.technion.ac.il/wp-content/uploads/2017/11/M.-Kent-Anderson.pdf (accessed on 15 April 2021).

9. Anjana, N.S.; Amarnath, A.; Harindranathan Nair, M.V. Toxic hazards of ammonia release and population vulnerability assessment using geographical information system. J. Environ. Manag. 2018, 210, 201-209. [CrossRef] [PubMed]

10. Apostolou, D.; Xydis, G. A literature review on hydrogen refuelling stations and infrastructure. Current status and future prospects. Renew. Sustain. Energy Rev. 2019, 113, 109292. [CrossRef]

11. Aziz, M.; TriWijayanta, A.; Nandiyanto, A.B.D. Ammonia as effective hydrogen storage: A review on production, storage and utilization. Energies 2020, 13, 3062. [CrossRef]

12. Baldi, F.; Azzi, A.; Maréchal, F. From renewable energy to ship fuel: Ammonia as an energy vector and mean for energy storage. Comput. Aided Chem. Eng. 2019, 46, 1747-1752. [CrossRef]

13. Baldi, F.; Moret, S.; Tammi, K.; Maréchal, F. The role of solid oxide fuel cells in future ship energy systems. Energy 2020, 194, 116811. [CrossRef] 
14. Baniasadi, E.; Dincer, I. Energy and exergy analyses of a combined ammonia-fed solid oxide fuel cell system for vehicular applications. Int. J. Hydrog. Energy 2011, 36, 11128-11136. [CrossRef]

15. Barelli, L.; Bidini, G.; Cinti, G. Operation of a solid oxide fuel cell based power system with ammonia as a fuel: Experimental test and system design. Energies 2020, 13, 6173. [CrossRef]

16. Ben-Daya, M.; Knezevic, J.; Raouf, A.; Ait-Kadi, D. Handbook of Maintenance Management and Engineering, 1st ed.; Ben-Daya, M., Knezevic, J., Raouf, A., Ait-Kadi, D., Eds.; Springer: Heidelberg, Germany, 2009; Volume 1. [CrossRef]

17. Bertsche, B. Reliability in Automotive and Mechanical Engineering, 1st ed.; Springer: Heidelberg, Germany, 2007. [CrossRef]

18. Bicer, Y.; Dincer, I. Environmental impact categories of hydrogen and ammonia driven transoceanic maritime vehicles: A comparative evaluation. Int. J. Hydrog. Energy 2018, 43, 4583-4596. [CrossRef]

19. Van Biert, L. Solid Oxide Fuel Cells for Ships: System Integration Concepts with Reforming Thermal Cycles. Ph.D. Thesis, TU Delft University, Delft, The Netherlands, 2020. [CrossRef]

20. Van Biert, L.; Godjevac, M.; Visser, K.; Aravind, P.V. A review of fuel cell systems for maritime applications. J. Power Sources 2016, 327, 345-364. [CrossRef]

21. Borunda, M.; Jaramillo, O.A.; Reyes, A.; Ibargüengoytia, P.H. Bayesian networks in renewable energy systems: A bibliographical survey. Renew. Sustain. Energy Rev. 2016, 62, 32-45. [CrossRef]

22. Bourne, C.; Nietsch, T.; Griffiths, D.; Morley, J. Applications of Fuel Cells in Surface Ships; DTI Sustainable Energy Programmes. 2001. Available online: https:/ / www.osti.gov/etdeweb/biblio/20249928 (accessed on 12 April 2021).

23. Brinks, H. Ammonia as a marine fuel. In Proceedings of the Alternative Fuels Online Conference, Online, 15 October 2020.

24. Budi Santosa, H.; Kasim, F.; Yudha Prasetyo, E.; Yahya Ayash, M. Mitigating accidental ammonia $\left(\mathrm{NH}_{3}\right)$ release from storage tank based on risk distribution using ALOHA and fault tree analysis in PT. AIP Conf. Proc. 2020, 2223, 40006. [CrossRef]

25. Cai, B.; Kong, X.; Liu, Y.; Lin, J.; Yuan, X.; Xu, H.; Ji, R. Application of Bayesian Networks in Reliability Evaluation. IEEE Trans. Ind. Inform. 2019, 15, 2146-2157. [CrossRef]

26. Camilo Gomez Trillos, J.; Wilken, D.; Brand, U.; Vogt, T.; GTrillos, J.C.; Brand, U.; Vogt, T.; Wilken, D. Life cycle assessment of a hydrogen and fuel cell ropax ferry prototype. In Progress in Life Cycle Assessment 2019; Springer: Berlin, Germany, 2019. [CrossRef]

27. CDNSWC. Handbook of Reliability Prediction Procedures for Mechanical Equipment; Carderockdiv, NSWC-92/L01; CDNSWC: Carderock, MD, USA, 2010.

28. Chisalita, D.-A.; Petrescu, L.; Cormos, C.-C. Environmental evaluation of european ammonia production considering various hydrogen supply chains. Renew. Sustain. Energy Rev. 2020, 130, 109964. [CrossRef]

29. Cinti, G.; Barelli, L.; Bidini, G. The use of ammonia as a fuel for transport: Integration with solid oxide fuel cells. AIP Conf. Proc. 2019, 2191. [CrossRef]

30. Cluster, O.H. Hydrogen and Ammonia Infrastructure Safety and Risk Information and Guidance; Lloyd's Register: London, UK, 2020.

31. Storwold, D.P. Detailed Test Plan for the Jack Rabbit Test Program; Analysis Center, Science and Technology Directorate: Washington, DC, USA, 2010.

32. Dammers, E.; McLinden, C.A.; Griffin, D.; Shephard, M.W.; Van Der Graaf, S.; Lutsch, E.; Schaap, M.; Gainairu-Matz, Y.; Fioletov, V.; Van Damme, M.; et al. $\mathrm{NH}_{3}$ emissions from large point sources derived from CrIS and IASI satellite observations. Atmos. Chem. Phys. Discuss. 2019, 19, 12261-12293. [CrossRef]

33. Damo, U.; Ferrari, M.; Turan, A.; Massardo, A. Solid oxide fuel cell hybrid system: A detailed review of an environmentally clean and efficient source of energy. Energy 2019, 168, 235-246. [CrossRef]

34. De-Troya, J.J.; Álvarez, C.; Fernández-Garrido, C.; Carral, L. Analysing the possibilities of using fuel cells in ships. Int. J. Hydrog. Energy 2016, 41, 2853-2866. [CrossRef]

35. Deniz, C.; Zincir, B. Environmental and economical assessment of alternative marine fuels. J. Clean. Prod. 2016, 113, 438-449. [CrossRef]

36. Det Norske Veritas (DNV). Technology Qualification; July 2013; Volume 81. Available online: http:/ / www2.dnvgl.com/DNV-RPA203 (accessed on 12 April 2021).

37. Dimopoulos, G.G.; Stefanatos, I.C.; Kakalis, N.M. Exergy analysis and optimisation of a marine molten carbonate fuel cell system in simple and combined cycle configuration. Energy Convers. Manag. 2016, 107, 10-21. [CrossRef]

38. DNV-GL. Use of Methanol as Fuel Methanol as Marine Fuel: Environmental Benefits, Technology Readiness, and Economic Feasibility, IMO; DNV-GL: Belum, Norway, 2016.

39. DNV-GL. Rules for Classifaction Part 6 Chapter 2 Propulsion, Power Generation and Auxiliary Systems. 2019. Available online: https:/ / rules.dnv.com/docs/pdf/DNV/RU-SHIP/2019-10/DNVGL-RU-SHIP-Pt6Ch2.pdf (accessed on 12 April 2021).

40. DNV GL. Assessment of Selected Ternative Fuels and technologies. Imo 2018, 391, 1-48. Available online: http:/ / www.imo.org/ en/KnowledgeCentre/IndexofIMOResolutions/Maritime-Safety-Committee-(MSC)/Documents/MSC.391(95).pdf (accessed on 12 April 2021).

41. DNV GL. Energy Transition Outlook 2020. A Global and Regional Forecast to 2050; DNV GL: Belum, Norway, 2020. [CrossRef]

42. Vostakola, M.F.; Horri, B.A. Progress in Material Development for Low-Temperature Solid Oxide Fuel Cells: A Review. Energies 2021, 14, 1280. [CrossRef]

43. Fuerte, A.; Valenzuela, R.; Escudero, M.; Daza, L. Ammonia as efficient fuel for SOFC. J. Power Sources 2009, 192, 170-174. [CrossRef] 
44. Giap, V.-T.; Lee, Y.D.; Kim, Y.S.; Ahn, K.Y.; Kim, D.H.; Lee, J.I. System simulation and exergetic evaluation of hybrid propulsion system for crude oil tanker: A hybrid of solid-oxide fuel cell and gas engine. Energy Convers. Manag. 2020, 223, 113265. [CrossRef]

45. Goldwire, H.C.J.; McRae, T.G.; Johnson, C.W.; Hipple, D.L.; Koopman, R.P.; McClure, J.W.; Morris, L.K.; Cederwall, R.T. Desert Tortoise Series Data Report; Lawrence Livermore National Laboratory: Livermore, CA, USA, 1983.

46. Gottesfeld, S. The Direct Ammonia Fuel Cell and a Common Pattern of Electrocatalytic Processes. J. Electrochem. Soc. 2018, 165, J3405-J3412. [CrossRef]

47. Grasham, O.; Dupont, V.; Camargo-Valero, M.A.; García-Gutiérrez, P.; Cockerill, T. Combined ammonia recovery and solid oxide fuel cell use at wastewater treatment plants for energy and greenhouse gas emission improvements. Appl. Energy 2019, 240, 698-708. [CrossRef]

48. Guo, Y.; Pan, Z.; An, L. Carbon-free sustainable energy technology: Direct ammonia fuel cells. J. Power Sources 2020, 476, 228454. [CrossRef]

49. Hagen, A.; Langnickel, H.; Sun, X. Operation of solid oxide fuel cells with alternative hydrogen carriers. Int. J. Hydrog. Energy 2019, 44, 18382-18392. [CrossRef]

50. Han, J.; Charpentier, J.-F.; Tang, T. An Energy Management System of a Fuel Cell/Battery Hybrid Boat. Energies 2014, 7, 2799-2820. [CrossRef]

51. Hansson, J.; Brynolf, S.; Fridell, E.; Lehtveer, M. The Potential Role of Ammonia as Marine Fuel—Based on Energy Systems Modeling and Multi-Criteria Decision Analysis. Sustainability 2020, 12, 3265. [CrossRef]

52. De Gusmão, A.P.H.; Silva, M.M.; Poleto, T.; e Silva, L.C.; Costa, A.P.C.S. Cybersecurity risk analysis model using fault tree analysis and fuzzy decision theory. Int. J. Inf. Manag. 2018, 43, 248-260. [CrossRef]

53. Huijsmans, J.; Kraaij, G.; Makkus, R.; Rietveld, G.; Sitters, E.; Reijers, H. An analysis of endurance issues for MCFC. J. Power Sources 2000, 86, 117-121. [CrossRef]

54. ICS. Reducing $\mathrm{CO}_{2}$ Emissions to Zero: The "Paris Agreement for Shipping"; International Chamber of Shipping: London, UK, 2018; Volume 16.

55. Igder, M.A.; Rafiei, M.; Boudjadar, J.; Khooban, M.-H. Reliability and Safety Improvement of Emission-Free Ships: Systemic Reliability-Centered Maintenance. IEEE Trans. Transp. Electrif. 2021, 7, 256-266. [CrossRef]

56. IMO. Annex 9, Resolution MEPC.213(63), 2012 Guidelines for the Development of a Ship Energy Efficiency Management Plan (SEEMP); IMO: London, UK, 2012.

57. IMO. Annex 5, Resolution MEPC.245(66), Guidelines on the Method of Calculation of the Attained Energy Efficiency Design Index (EEDI) for New Ships; IMO: London, UK, 2014.

58. IMO. Reducing Greenhouse Gas Emissions from Ships; IMO: London, UK, 2020; Available online: http://www.imo.org/en/ MediaCentre/HotTopics/Pages/Reducing-greenhouse-gas-emissions-from-ships.aspx (accessed on 4 May 2021).

59. Inal, O.B.; Deniz, C. Assessment of fuel cell types for ships: Based on multi-criteria decision analysis. J. Clean. Prod. 2020, 265, 121734. [CrossRef]

60. Isermann, R. Fault-Diagnosis Systems. An Introduction from Fault Detection to Fault Tolerance; Isermann, R., Ed.; Springer: Berlin/Heidelberg, Germany, 2006; ISBN 978-3-540-30368-8. Available online: https://link.springer.com/content/pdf/10 .1007\%2F3-540-30368-5.pdf (accessed on 12 April 2021).

61. Jeerh, G.; Zhang, M.; Tao, S. Recent progress in ammonia fuel cells and their potential applications. J. Mater. Chem. A 2021, 9 , 727-752. [CrossRef]

62. Jordan, J. Shipping Industry Needs to Look beyond IMO 2020 to Lower-Carbon Fuels. SEP Glob. Platts 2019. Available online: https:/ /blogs.platts.com/2019/07/24/shipping-beyond-imo-2020-lower-carbon/ (accessed on 1 April 2021).

63. Kang, J.; Sun, L.; Soares, C.G. Fault Tree Analysis of floating offshore wind turbines. Renew. Energy 2019, $133,1455-1467$. [CrossRef]

64. Kim, K.; Roh, G.; Kim, W.; Chun, K. A Preliminary Study on an Alternative Ship Propulsion System Fueled by Ammonia: Environmental and Economic Assessments. J. Mar. Sci. Eng. 2020, 8, 183. [CrossRef]

65. Kishimoto, M.; Muroyama, H.; Suzuki, S.; Saito, M.; Koide, T.; Takahashi, Y.; Horiuchi, T.; Yamasaki, H.; Matsumoto, S.; Kubo, H.; et al. Development of 1 kW-class Ammonia-fueled Solid Oxide Fuel Cell Stack. Fuel Cells 2020, 20, 80-88. [CrossRef]

66. Kobbacy, K.A. Complex System Maintenance Handbook, 1st ed.; Springer: Berlin/Heidelberg, Germany, 2008.

67. Lan, R.; Tao, S. Direct Ammonia Alkaline Anion-Exchange Membrane Fuel Cells. Electrochem. Solid-State Lett. 2010, 13, B83-B86. [CrossRef]

68. Lan, R.; Tao, S. Ammonia as a Suitable Fuel for Fuel Cells. Front. Energy Res. 2014, 2, 3-6. [CrossRef]

69. Langseth, H.; Portinale, L. Bayesian networks in reliability. Reliab. Eng. Syst. Saf. 2007, 92, 92-108. [CrossRef]

70. Lee, K.J.; Shin, D.; Lee, J.P.; Yoo, D.W.; Choi, H.K.; Kim, H.J. Hybrid photovoltaic/diesel green ship operating in standalone and grid-connected mode in South Korea-Experimental investigation. Energy 2012, 49, 580-583. [CrossRef]

71. Lewis, R.J.S. Hawley's Condensed Chemical Dictionary, 12th ed.; Van Nostrand Reinhold: New York, NY, USA, 1993.

72. Lindstad, H. GHG Emission Reduction Potential of EU-Related Maritime Transport and on its Impacts; TNO: The Hague, The Netherlands, 2015.

73. Lloyd's Register; UMAS. Techno-Economic Assessment of Zero-Carbon Fuels; Lloyds Register: London, UK, 2020.

74. Ma, Q.; Ma, J.; Zhou, S.; Yan, R.; Gao, J.; Meng, G. A high-performance ammonia-fueled SOFC based on a YSZ thin-film electrolyte. J. Power Sources 2007, 164, 86-89. [CrossRef] 
75. MAN Energy Solutions. Engineering the Future Two-Stroke Green-Ammonia Engine. 2019. Available online: https://marine.man-es. $\mathrm{com} /$ docs/librariesprovider6/test/engineering-the-future-two-stroke-green-ammonia-engine.pdf?sfvrsn=7f4dca2_4 (accessed on 1 April 2021).

76. Mardones, C.; Flores, B. Effectiveness of a $\mathrm{CO}_{2}$ tax on industrial emissions. Energy Econ. 2018, 71, 370-382. [CrossRef]

77. Mazloomi, K.; Gomes, C. Hydrogen as an energy carrier: Prospects and challenges. Renew. Sustain. Energy Rev. 2012, 16, 3024-3033. [CrossRef]

78. Mckinlay, C.J.; Turnock, S.R.; Hudson, D.A. A Comparison of hydrogen and ammonia for future long distance shipping fuels. In Proceedings of the LNG/LPG and Alternative Fuels Ships Conference, London, UK, 29-30 January 2020.

79. McMahon, J. Get Ready for 1.5\$ Renewable Electricity, Steven Chu Says, Which Could Unleash Hydrogen Economy. 2019. Available online: https://www.forbes.com/sites/jeffmcmahon/2019/04/02/get-ready-for-1-5\protect $\backslash$ includegraphics[scale=1] \{Definitions/energies-1217574-i002.pdf\}\}-renewable-electricity-steven-chu-says-which-could-unleash-hydrogen-economy / ?sh=342c3a601c01 (accessed on 1 April 2021).

80. MEPC. Reduction of GHG emissions from ships. Fourth IMO GHG Study 2020. IMO 2020, 53. [CrossRef]

81. Mobley, K.; Higgins, L.; Wikoff, D. Maintenance Engineering Handbook, 7th ed.; Mobley, R.K., Ed.; McGraw Hill: New York, NY, USA, 2008. [CrossRef]

82. Mohanty, A.R. Machinery Condtion Monitoring, 1st ed.; Taylor \& Francis: Abingdon, UK, 2015.

83. Mokashi, A.; Wang, J.; Vermar, A. A study of reliability-centred maintenance in maritime operations. Mar. Policy 2002, 26, 325-335. [CrossRef]

84. Namboothiri, N.V.; Soman, A. Consequence assessment of anhydrous ammonia release using CFD-probit analysis. Process. Saf. Prog. 2018, 37, 525-534. [CrossRef]

85. National Research Council. Acute Exposure Guideline Levels for Selected Airborne Chemicals: Volume 6; The National Academics Press: New York, NY, USA, 2007.

86. National Research Council. Acute Exposure Guideline Levels for Selected Airborne Chemicals: Volume 6; National Academies Press (US): New York, NY, USA, 2008.

87. NCE. Norwegian Future Value Chains for Liquid Hydrogen; NCE Maritime CleanTech: Stord, Norway, 2019; Volume 84, Available online: https:/ / maritimecleantech.no/wp-content/uploads/2016/11/Report-liquid-hydrogen.pdf?fbclid=IwAR3uqivsh0dF3 _VBQd8UB_0cgVtnf3XIM1of2xG7Y2WAS07e3OHzoTT-_9Q (accessed on 1 April 2021).

88. Nielsen, M.; Bengtsson, R.; Jones, C.; Nyrén, K.; Ott, S.; Ride, D. Design of the Fladis Field Experiments with Dispersion of Liquefied Ammonia; US Department of Energy: Washington, DC, USA, 1994.

89. Nielsen, M.; Ott, S. Fladis Field Experiments, Final Report; Riso National Laboratory: Roskilde, Denmark, 1996.

90. OECD. Decarbonising Maritime Transport. Pathways to Zero-Carbon Shipping by 2035; International Transport Forum, 2018; Volume 86. Available online: https://www.itf-oecd.org/sites/default/files/docs/decarbonising-maritime-transport.pdf (accessed on 5 May 2021).

91. Okanishi, T.; Okura, K.; Srifa, A.; Muroyama, H.; Matsui, T.; Kishimoto, M.; Saito, M.; Iwai, H.; Yoshida, H.; Koide, T.; et al. Comparative Study of Ammonia-fueled Solid Oxide Fuel Cell Systems. Fuel Cells 2017, 17, 383-390. [CrossRef]

92. Pearl, J. Bayesian Networks: A Model of Self-Activated Memory for Evidential Reasoning; UCLA: Los Angeles, CA, USA, 1985.

93. Pearl, J. Prpbabilistic reasoning in intelligent systems. In Probabilistic Reasoning in Intelligent Systems, 2nd ed.; Morgan, M.B., Ed.; Morgan Kaufmann: San Francisco, CA, USA, 1988. [CrossRef]

94. Rausan, M.; Hoyland, A. System Reliability Theory: Models, Statistical Methods, and Applications, 2nd ed.; Shewhart, W., Wilks, S., Eds.; Wikey \& Sons: Hoboken, NJ, USA, 2004.

95. Rosli, R.; Sulong, A.; Daud, W.; Zulkifley, M.; Husaini, T.; Rosli, M.; Majlan, E.H.; Haque, M. A review of high-temperature proton exchange membrane fuel cell (HT-PEMFC) system. Int. J. Hydrog. Energy 2017, 42, 9293-9314. [CrossRef]

96. Ruijters, E.; Stoelinga, M. Fault tree analysis: A survey of the state-of-the-art in modeling, analysis and tools. Comput. Sci. Rev. 2015, 15-16, 29-62. [CrossRef]

97. RVIM. Guidelines for Quantitative Risk Assessment (Purple Book) CPR 18E; Publicatiereeks Gevaarlijky Stoffen: Rotterdam, The Netherlands, 2005.

98. ShipFC. Grant Agreement Number: 875156-ShipFC, 2019.

99. Siddiqui, O.; Ishaq, H.; Dincer, I. Experimental investigation of improvement capability of ammonia fuel cell performance with addition of hydrogen. Energy Convers. Manag. 2020, 205, 112372. [CrossRef]

100. Silva, J.C.M.; Da Silva, S.G.; De Souza, R.F.; Buzzo, G.S.; Spinacé, E.V.; Neto, A.O.; Assumpção, M.H. PtAu/C electrocatalysts as anodes for direct ammonia fuel cell. Appl. Catal. A Gen. 2015, 490, 133-138. [CrossRef]

101. Singhal, S. Solid oxide fuel cells for stationary, mobile, and military applications. Solid State Ion. 2002, 152-153, 405-410. [CrossRef]

102. Smith, R.; Mobley, K. Rules of Thumb for Maintenance and Reliability Engineers, 1st ed.; Butterworth-Heinemann: Woburn, MA, USA, 2008. [CrossRef]

103. Spreafico, C.; Russo, D.; Rizzi, C. A state-of-the-art review of FMEA/FMECA including patents. Comput. Sci. Rev. 2017, 25, 19-28. [CrossRef]

104. Stoeckl, B.; Preininger, M.; Subotić, V.; Megel, S.; Folgner, C.; Hochenauer, C. Towards a wastewater energy recovery system: The utilization of humidified ammonia by a solid oxide fuel cell stack. J. Power Sources 2020, 450, 227608. [CrossRef]

105. Stopford, M. Three Maritime Scenarios 2020-2050; Seatrade Maritime: Colchester, UK, 2020. 
106. The Royal Society. Ammonia: Zero-Carbon Fertiliser, Fuel and Energy Store. Policy Briefing; Issue Accessed 25 August 2020; 2020. Available online: https://royalsociety.org/-/media/policy/projects/green-ammonia/green-ammonia-policy-briefing.pdf (accessed on 1 March 2021).

107. Thiem, C.; Gentner, C.; Ackermann, G. Methanol powered fuel cell systems for marine applications. In Proceedings of the International Conference on Shipping in Changing Climates Technologies, Operations, Logistics and Policies towards Meeting 2050 Emission Targets, Glasgow, UK, 7 September-8 September 2015.

108. Tixier, J.; Dusserre, G.; Salvi, O.; Gaston, D. Review of 62 risk analysis methodologies of industrial plants. J. Loss Prev. Process. Ind. 2002, 15, 291-303. [CrossRef]

109. TNO. Methods for the Determination of Possible Damage to People and Objects Resulting from Releases of Hazardous Materials (Green Book); Instituut voor Milieu- en Energietechnologie TNO Prins Maurits Laboratorium TNO, Ed.; Committee for the Prevention of Disasters: Den Haag, The Netherlands, 1992.

110. TNO. Methods for the Calculation of Physical Effects due to Releases of Hazardous Materials (Yellow Book) CPR 14E, 3rd ed.; Publicatiereeks Gevaarlijke Stoffen 2: Rotterdam, The Netherlands, 2005.

111. Tronstad, T.; Åstrand, H.H.; Haugom, G.P.; Langfeldt, L. Study on the Use of Fuel Cells in Shipping; EMSA, EU: Lisbon, Portugal, 2017.

112. UNCTAD. Review of Maritime Transport. J. Chem. Inf. Modeling 2020, 53. Available online: https://unctad.org/system/files/ official-document/rmt2020_en.pdf (accessed on 1 March 2021).

113. US Department of Energy. Comparison of Fuel Cell Technologies; Fuel Cell Technology Offices: Washington, DC, USA, 2016. [CrossRef]

114. Utah Valley University. Jack Rabbit Project. 2010. Available online: https://www.uvu.edu/es/jack-rabbit/ (accessed on 1 March 2021).

115. Uwemedimo, E.; Doymus, M.; Eylul, D. Understanding regulations, sustainable shipping, alternative marine fuels and LNG. In Proceedings of the 8th Global LNG Bunkering Summit 2020, Amsterdam, The Netherlands, 28-30 January 2020.

116. Wan, Z.; Tao, Y.; Shao, J.; Zhang, Y.; You, H. Ammonia as an effective hydrogen carrier and a clean fuel for solid oxide fuel cells. Energy Convers. Manag. 2021, 228, 113729. [CrossRef]

117. Weast, R.C. CRC Handbook of Chemistry and Physics, 65th ed.; Astle, M., Beyer, W.H., Eds.; CRC Press: Boca Raton, FL, USA, 1984.

118. Wojcik, A.; Middleton, H.; Damopoulos, I.; Van Herle, J. Ammonia as a fuel in solid oxide fuel cells. J. Power Sources 2003, 118, 342-348. [CrossRef]

119. Xing, H.; Spence, S.; Chen, H. A comprehensive review on countermeasures for $\mathrm{CO}_{2}$ emissions from ships. Renew. Sustain. Energy Rev. 2020, 134, 110222. [CrossRef]

120. Yu, X.; Ye, S. Recent advances in activity and durability enhancement of Pt/C catalytic cathode in PEMFC. J. Power Sources 2007, 172, 133-144. [CrossRef]

121. Zhang, J.; Xie, Z.; Zhang, J.; Tang, Y.; Song, C.; Navessin, T.; Shi, Z.; Song, D.; Wang, H.; Wilkinson, D.P.; et al. High temperature PEM fuel cells. J. Power Sources 2006, 160, 872-891. [CrossRef]

122. Zhao, Y.; Setzler, B.P.; Wang, J.; Nash, J.; Wang, T.; Xu, B.; Yan, Y. An Efficient Direct Ammonia Fuel Cell for Affordable Carbon-Neutral Transportation. Joule 2019, 3, 2472-2484. [CrossRef] 